\title{
DEVELOPMENT OF NEW BIODEGRADABLE ALLOYS FOR MEDICAL APPLICATIONS
}

\author{
'Zuzana MOLČANOVÁ, 'Beáta BALLOKOVÁ, 2Juraj ĎURIŠIN, 1,2Katarína ŠUL'OVÁ, \\ ${ }^{3}$ Michaela ŠULIKOVÁ, ${ }^{3}$ Andrea LACHOVÁ, ${ }^{3}$ Maksym LISNICHUK, ${ }^{1,3}$ Miloš FEJERČÁK, \\ ${ }^{3}$ Slávka MARTINKOVÁ, ${ }^{4}$ Štefan MICHALIK, ${ }^{1,3,{ }^{*} \text { Karel SAKSL }}$ \\ ${ }^{1}$ Institut of Materials Research, Slovak Academy of Sciences, Košice, Slovak Republic, EU, \\ molcanova@saske.sk, bballokova@saske.sk, ksulova@saske.sk, milos.fejercak@gmail.com \\ ${ }^{2}$ Technical University of Košice, Košice, Slovak Republic, EU, juraj.durisin@tuke.sk \\ ${ }^{3}$ Pavol Jozef Šafárik University in Košice, Košice, Slovak Republic, EU, michaela.sulikova1@student.upjs.sk, \\ lachova.ada@gmail.com, slavka.martinkova@gmail.com \\ ${ }^{4}$ Diamond Light Source Ltd., Harwell Science and Innovation Campus, Didcot, United Kingdom, EU, \\ stefan.michalik@diamond.ac.uk \\ * Corresponding author. Tel.: +421 55 7922457; Fax: +421 55 7922408, ksaksl@saske.sk \\ https://doi.org/10.37904/metal.2019.745
}

\begin{abstract}
In surgery, besides the joint replacements that need permanent prosthesis implantation in the human body, there are many other clinical cases, such as bone fracture, cardiovascular diseases, in which the temporary implant materials are needed. The fixation or mechanical support are there temporarily needed during the healing process of the injured or pathological tissue, and after that, the implants accomplish their mission have no longer function in human body. In this case, biodegradable materials are the optimal choice as these materials do their job while healing and a new tissue forming occur and degrade in the human body thereafter. Amorphous alloys based on magnesium and calcium are nowadays a very perspective group of metallic glasses. We have developed composition series of completely new (not published) ternary Ca-Mg-Au biodegradable alloys with attractive properties in terms of possible future applications (density and elastic modulus comparable to human bones, wide supercooled liquid region etc.). Although the rate of their degradation in physiological solutions is still too fast, these ternary alloys will serve as precursors for design of future highly alloyed systems with tuned dissociation rate in human body.
\end{abstract}

Keywords: Biodegradable alloys, X-ray diffraction, nanoindentation, alloy dissolution

\section{INTRODUCTION}

The progressive ageing of the world's population has increased the need for improved and longer-lasting materials for use in biomedical devices. The majority of current medical devices are either made of ceramics or metallic alloys composed mainly of titanium, which is known for its reliable biocompatibility. However, the most well known of these common titanium alloys, Ti-6Al-4V, contain vanadium and aluminium. The latter element has been identified as potentially toxic. The design of a new alloy that provides reliable mechanical characteristics without negative effects on the human body is a current challenge for the biomedical sector. Another issue associated with today used materials for orthopaedic implants are that the existing hard tissue biomaterials are employed as permanent fixation devices which are used primarily in load-bearing applications. Examples include bone plates, staples, suture anchors, screws and pins to secure fractures, along with dental implants. However, most fracture fixation devices are removed after healing, requiring invasive procedures and additional costs. In case of load-bearing, fracture fixation devices, such as intramedullary rods or bone plates, stress shielding (bone becomes weaker due to transfer of normal stresses to stiffer implant) is another challenge associated with their permanent in-vivo presence [1,2]. There exist clinical cases such as cardiovascular diseases or bone fracture where only temporary implant materials are needed. For such cases the fixation or mechanical support are needed for just the healing process, and after it the implants should 
dissolve in the human body and feed surrounding local tissue. For these reasons, interest in bioresorbable metallic vascular scaffolds and orthopaedic fracture fixation devices has increased in the last decade [3]. Biodegradable or bioresorbable materials based on $\mathrm{Mg}$ and $\mathrm{Ca}$ elements are the optimal choice as those materials consist of elements pre-existing in the human body to which the organism has an inherent tolerance. Implants in these cases will do their job while healing and new tissue forming occurs and degrades in the human body thereafter. To achieve the ultimate orthopaedic resorbable tissue implant, a series of general conditions need to be fulfilled before the material can be used clinically [4]:

- $\quad$ cell response: encourage new bone formation through both osteoblast and osteoclast attachment and proliferation, but also avoid fibrous capsule formation [5]

- mechanical integrity: $>6$ months

- $\quad$ yield strength and ultimate tensile strength: $>230 \mathrm{MPa}$ and $>300 \mathrm{MPa}$

- $\quad$ elongation to failure: $>15-18 \%$

- $\quad$ elastic modulus: close to cortical bone to avoid stress-shielding (10-20 GPa)

- $\quad$ fatigue strength at $10^{7}$ cycles (MPa): :256

- hydrogen evolution: $<10 \mu \mathrm{L} / \mathrm{cm}^{2} /$ day

This work reports our development of a brand new fully biocompatible bulk metallic glass based on $\mathrm{Mg}, \mathrm{Ca}$ and $\mathrm{Au}$. Our alloys development is based on machine learning prediction described in the article [6].

\section{MATERIAL SELECTION}

The alloys selection was based on the condition that the elements that will be used are exclusively biocompatible. The choice of the chemical composition of alloys that could form metal glass is based on the new machine learning prediction approach described in the article F. Ren et al. [6]. The result of this prediction is shown on the Mg-Ca-Au ternary alloy as probabilistic colour map where the most probable compositions to form metallic glass are in red colour, see Figure 1. We decided to experimentally verify compositions laying on concentration of Au up to 10 at.\%. Our selections are marked in the figure by squares and circles.

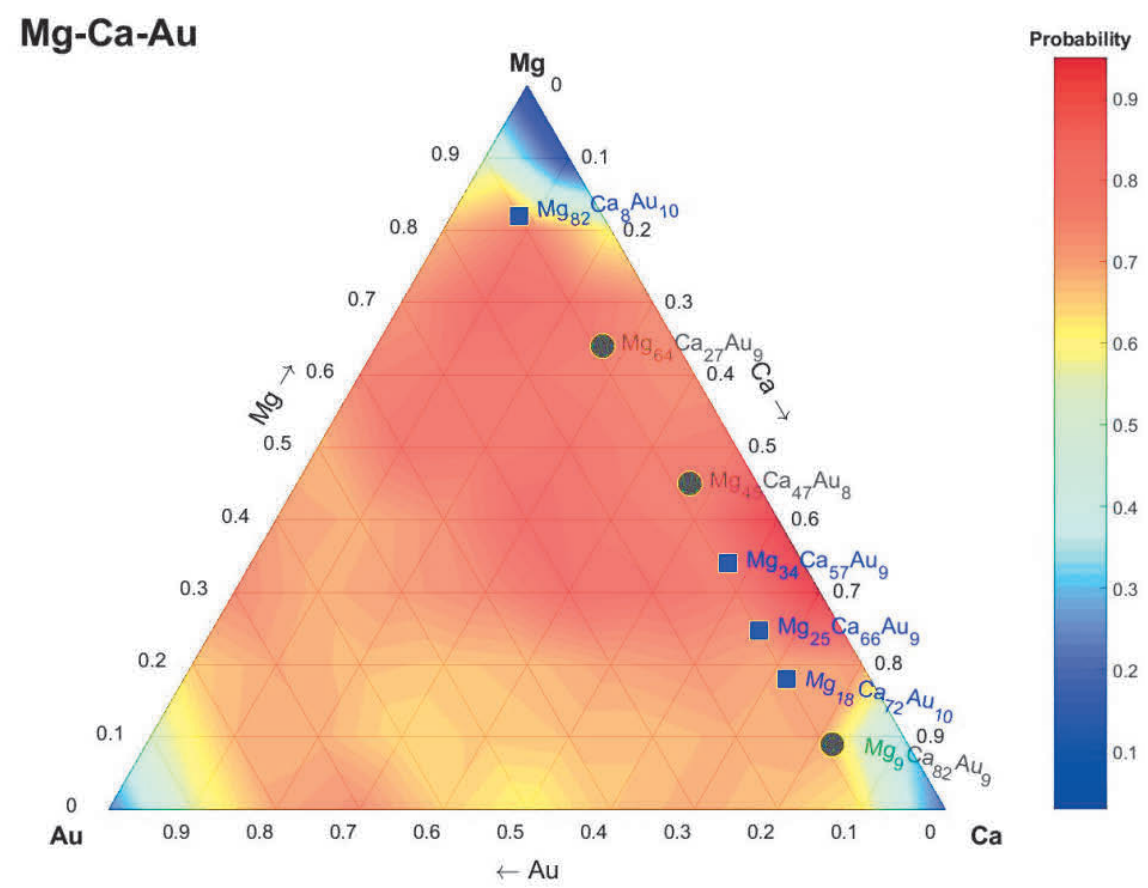

Figure $1 \mathrm{Mg}$-Ca-Au ternary diagram showing in colour map prediction of glass forming probability calculated by machine learning algorithm, the alloys which were tested experimentally are marked by squares and circles 


\section{MATERIAL}

\subsection{Preparation}

The Mg-Ca-Au alloys of different compositions were fabricated by induction melting of the pure constituent elements (Ca 99.5 wt\% Mg 99.98 wt\% and Au 99.99 wt\%) in a BN coated quartz tube under a high vacuum (better than $3.0 \times 10^{-3} \mathrm{~Pa}$ ) at $1000{ }^{\circ} \mathrm{C}$. Ribbons of maximum thickness of $40 \mu \mathrm{m}$, width $\sim 4 \mathrm{~mm}$ and length below $70 \mathrm{~mm}$ were prepared by the single-roller melt-spinning method.

\subsection{Characterization}

The density of the alloys was measured at room temperature applying Archimedean principle using a analytical balance Kern ABT 120-4M with special density determination kit ABT-A01. Measurements were performed in oil of density $0.882 \mathrm{~g} / \mathrm{cm}^{3}$.

Elastic modulus of the alloys was determined by nanoindentation experiment conducted using the NHT, CSM nanoindenter instruments calibrated on pure fused silica. The indenter tip was a diamond Berkovich indenter (three sided pyramid) and the results were evaluated using the Oliver-Pharr method. Indentation was performed in single load mode to loads as high as $50 \mathrm{mN}$ using the loading rate $1 \mathrm{mN} / \mathrm{s}$, with dwell time $10 \mathrm{~s}$.

Thermal stability of the alloys was ascertained by Perkin Elmer power-compensated differential scanning calorimeter (DSC 8000) at scan rate of $10 \mathrm{~K} \cdot \mathrm{min}^{-1}$. Measurement was carried out in graphite sample pans under pure argon atmosphere. The temperature and the enthalpy were calibrated by using pure In and $\mathrm{Zn}$. Each measurement was followed by a second run to determine baseline of the measurement.

To determine phase composition a hard X-ray diffraction experiment was performed at the beamline I15-1 located at the Diamond Light Source (electron storage ring operating at an energy of $3 \mathrm{GeV}$ with beam current $\sim 300 \mathrm{~mA}$ operating in top-up mode). During the experiment, monochromatic synchrotron radiation of photon energy $76.69 \mathrm{keV}(\lambda=0.016166 \mathrm{~nm})$ was applied. The following setup was applied: transmission (DebyeScherrer) geometry; monochromatized high energy $X$-ray beam of photon energy $76.69 \mathrm{keV}(\lambda=0.016166$ $\mathrm{nm})$ to obtain high quality diffraction patterns up to the magnitude of the scattering vector $Q_{\max }=4 \pi \sin (\theta) / \lambda=2$ $\mathrm{nm}^{-1}$; beam cross-section on the sample was $\sim 0.7 \mathrm{~mm} \times 0.15 \mathrm{~mm}(\mathrm{~h} \times \mathrm{v})$; fast 2D image plate detector Perkin Elmer XRD 4343 CT (2880 pixels $\times 2880$ pixels, size of a pixel: $150 \mu \mathrm{m} \times 150 \mu \mathrm{m})$ to record diffracted X-rays. After corrections for the background, polarization, absorption and Compton scattering the scattering intensity was converted to the X-ray total structure factor using the PdfGetX2 software [7].

We have investigated also degradation behaviour of the alloys by immersion the alloys to the Hanks' balanced salt solution (H6648) and documented their degradation by photographing the alloy at regular time intervals.

\section{RESULTS AND DISCUSSION}

Figure 2a shows $\mathrm{X}$-ray structure factors calculated from the $\mathrm{X}$-ray diffraction measurement. From this figure it is evident that the alloys of the composition $\mathrm{Mg}_{64} \mathrm{Ca}_{27} \mathrm{Au}_{9}, \mathrm{Mg}_{45} \mathrm{Ca}_{47} \mathrm{Au}_{8}$ and $\mathrm{Mgg}_{9} \mathrm{Ca}_{82} \mathrm{Au}_{9}$ are crystalline, (marked by grey circles on the Figure 1), while the $\mathrm{Mg}_{82} \mathrm{Ca}_{8} \mathrm{Au}_{10}, \mathrm{Mg}_{34} \mathrm{Ca}_{57} \mathrm{Au}{ }_{9}, \mathrm{Mg}_{25} \mathrm{Ca} 6{ }_{6} \mathrm{Au} 9$ and $\mathrm{Mg}_{18} \mathrm{Ca}_{72} \mathrm{Au}_{10}$ alloys were prepared in fully amorphous state (squares). Figure $\mathbf{2 b}$ shows reduced atomic pair distribution functions $D(r)$ of the corresponding $S(Q)$ 's. Since we have prepared a series of different compositions, it is interesting to see changes in first coordination shell, by altering the $\mathrm{Mg}$ - Ca ratio. Individual atomic pairs with indicated X-ray weights are shown for one particular amorphous alloy in the Figure 2c.

Chemical composition determined by the EDX analysis, phase composition, elastic modulus, nanohardness as well as the characteristic phase transformation temperatures of the Mg-Ca-Au alloys are listed in Table 1. By comparing the results we can formulate the following conclusions:

- $\quad$ with increase of calcium content, the modulus of elasticity in the alloy decreases. $\mathrm{Th} \mathrm{Mg}_{25} \mathrm{Ca}_{66} \mathrm{Au}_{10}$ has the lowest EIT value which is close to a value typical for cortical bone. 
- nanohardness of the amorphous alloys is in the range of $2.4-2.7 \mathrm{GPa}$, whereas for crystal samples the values varies considerably more.

- $\quad$ super-cooled liquid region (important technological parameter for thermoplastic forming of the material) is in the case of $\mathrm{Mg}_{34} \mathrm{Ca}_{57} \mathrm{Au}_{9}$ extraordinarily wide $80^{\circ} \mathrm{C}$. This parameter also confirms that the $\mathrm{Mg}_{34} \mathrm{Ca}_{57}$ Au9 composition is close to deep eutectic of this ternary system. Such observation is in good agreement with the machine learning prediction.

- As expected, the alloy density decreases with increasing Ca content at the expense of Mg. The lowest measured density $2.04 \mathrm{~g} . \mathrm{cm}^{-3}$ is close the value reported for of non-porous cortical bones $1.9 \mathrm{~g} . \mathrm{cm}^{-3}$.
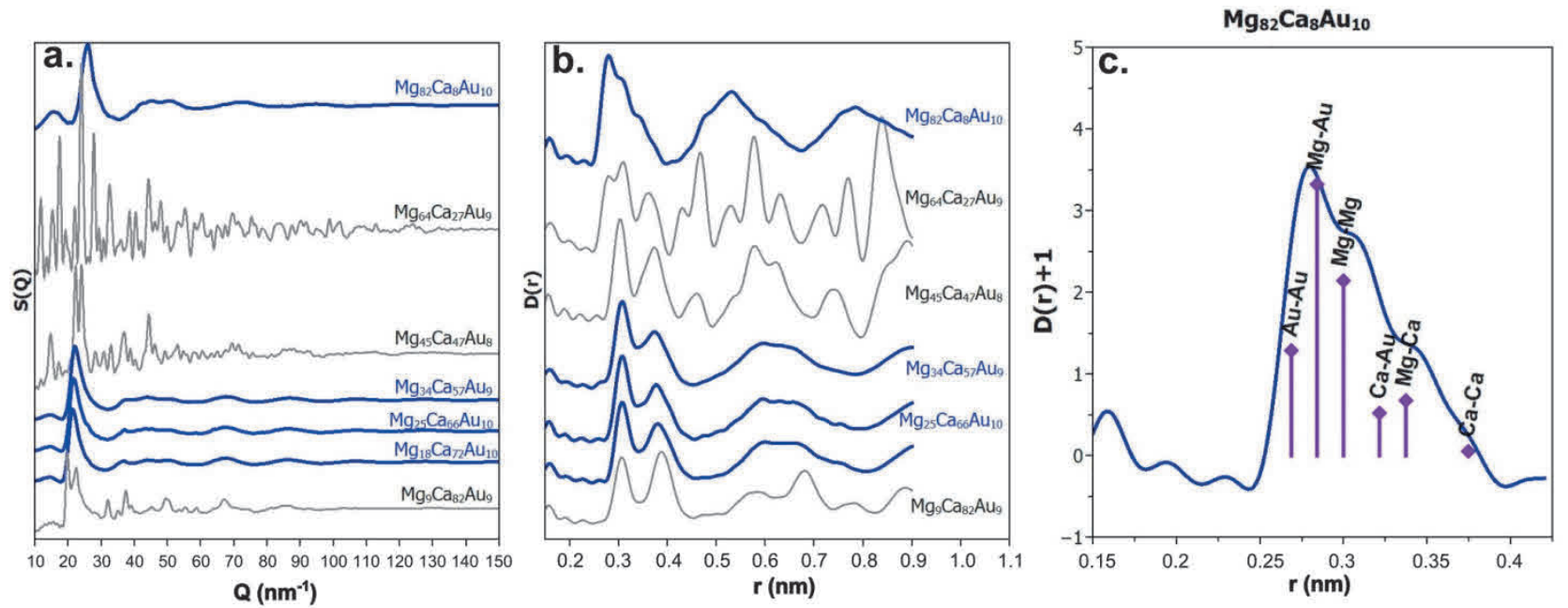

Figure 2 a. The total X-ray structure factors, b. corresponding reduced atomic pair distribution functions $D(r)$,

c. $D(r)$ of the $\mathrm{Mg}_{82} \mathrm{Ca}_{8} \mathrm{Au}_{10}$ corresponding to the first coordination shell shown together with interatomic metallic (Goldschmidt) bond lengths and X-ray weights of the $\mathrm{Mg}-\mathrm{Mg}, \mathrm{Mg}-\mathrm{Ca}, \mathrm{Mg}-\mathrm{Au}, \mathrm{Ca}-\mathrm{Ca}, \mathrm{Ca}-\mathrm{Au}$ and $\mathrm{Au}-$ Au atomic pairs

The degradation of the sample in physiological solution is shown in Figure $\mathbf{3}$ where the upper row presents photographs of the alloys prior to immersion into the saline. The lower row of Figure 3 shows the same alloys but after 6 minutes of exposure in the Hank's salt solution. From this photo documentation it is obvious that all the alloys are dissolving in the saline but with different rate. We have estimated rate of the samples dissolution 6 minutes after immersion and our estimations are listed in the last column of Table 1.

Table 1 Properties of the Mg-Ca-Au alloys, from left to right EDX determined chemical composition, phase composition (A - amorphous C - crystalline phase), $E_{I T-}$ elastic modulus $H_{I T}$ - hardness both determined by nanoindentation, $T_{g}$ - glass transition temperature, $T_{x 1}$ onset - onset of the $1^{\text {th }}$ crystallisation temperature, $\boldsymbol{\Delta} \boldsymbol{T}$ - supercooled liquid region, $\boldsymbol{\rho}$ - density and $\boldsymbol{c r}$ - corrosion rate estimated 6 minutes after immersion alloys into the Hank's salt solution

\begin{tabular}{|c|c|c|c|c|c|c|c|c|}
\hline Alloy & Phase & $E_{I T}(\mathrm{GPa})$ & $H_{I T}(\mathrm{GPa})$ & $T_{g}\left({ }^{\circ} \mathrm{C}\right)$ & $T_{x 1}$ onset $\left({ }^{\circ} \mathrm{C}\right)$ & $\Delta T\left({ }^{\circ} \mathrm{C}\right)$ & $\rho\left(\mathrm{g} \cdot \mathrm{cm}^{-3}\right)$ & $\operatorname{cr} \times 10^{-4}(\mathrm{~mm} / \mathrm{s})$ \\
\hline $\mathrm{Mg}_{82} \mathrm{Ca}_{8} \mathrm{Au}_{10}$ & A & $44 \pm 1$ & $2.65 \pm 0.06$ & 99 & 139 & 40 & 2.75 & 5.4 \\
\hline $\mathrm{Mg}_{64} \mathrm{Ca}_{27} \mathrm{Au}_{9}$ & C & $34 \pm 7$ & $4.9 \pm 0.3$ & & & & 2.63 & 6.4 \\
\hline $\mathrm{Mg}_{45} \mathrm{Ca}_{47} \mathrm{Au}_{8}$ & $\mathrm{C}$ & $34.9 \pm 0.4$ & $3.72 \pm 0.06$ & & & & 2.57 & 0.5 \\
\hline $\mathrm{Mg}_{34} \mathrm{Ca}_{57} \mathrm{Au}_{9}$ & A & $37.9 \pm 0.6$ & $2.64 \pm 0.08$ & 74 & 154 & 80 & 2.45 & 2.1 \\
\hline $\mathrm{Mg}_{25} \mathrm{Ca}_{66} \mathrm{Au}_{9}$ & $\mathrm{~A}$ & $20 \pm 1$ & $2.39 \pm 0.04$ & 78 & 120 & 42 & 2.41 & 1.2 \\
\hline $\mathrm{Mg}_{18} \mathrm{Ca}_{72} \mathrm{Au}_{10}$ & $\mathrm{~A}$ & $27 \pm 1$ & $2.4 \pm 0.2$ & 83 & 107 & 24 & 2.40 & 5.8 \\
\hline $\mathrm{Mg}_{9} \mathrm{Ca}{ }_{82} \mathrm{Au} 9$ & C & $23 \pm 2$ & $1.8 \pm 0.2$ & & & & 2.04 & 10.7 \\
\hline
\end{tabular}



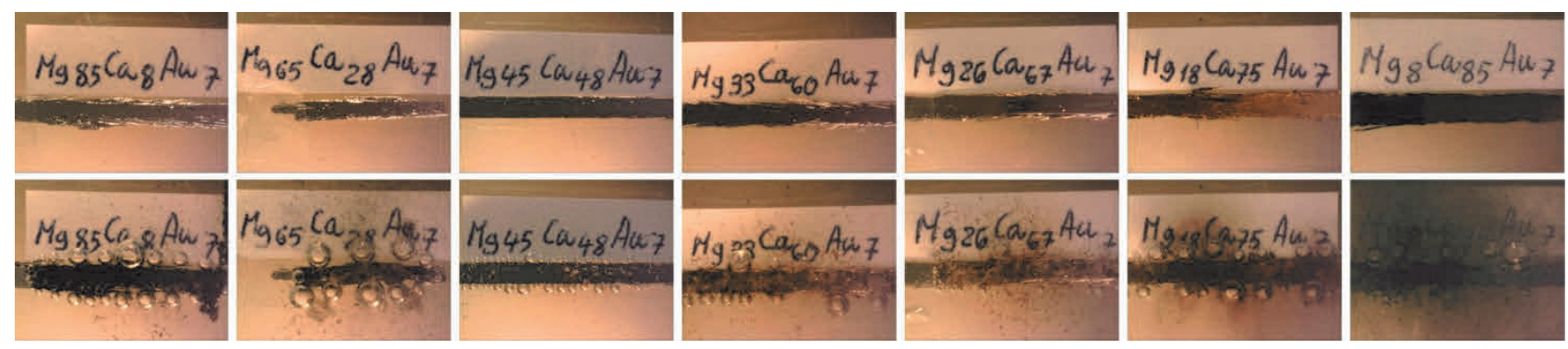

Figure 3 upper row: photographs of the alloys prior to immersion to physiological solution, lower row: the same alloys after 6 minutes exposure in the Hank's salt solution

\section{CONCLUSION}

In this paper we report our development of a brand new fully biocompatible bulk metallic glass based on $\mathrm{Mg}$, $\mathrm{Ca}$ and $\mathrm{Au}$ elements. Design of the alloys was based on machine learning prediction described in the work of F. Ren et al. [6]. In the range of gold concentrations up to 10 at.\% we have identified compositional areas that can be prepared to fully amorphous state by rapid quenching method with critical cooling rate $\sim 10^{5} \mathrm{~K}^{-1}$., see Figure 1. The amorphous alloys have hardness ranging from 2.4 to $2.7 \mathrm{GPa}$ and elastic modulus between 27 to $44 \mathrm{GPa}$. The alloy $\mathrm{Mg}_{34} \mathrm{Ca}_{57} \mathrm{Au}$ 9 exhibits extraordinarily wide $80^{\circ} \mathrm{C}$ super-cooled liquid region. The corrosion/degradation rate of these alloys has been estimated 6 minutes after immersion into the Hank's salt solution, see Table 1 and Figure 3.

\section{ACKNOWLEDGEMENTS}

This work was realized within the framework of the project „Research Centre of Advanced Materials and Technologies for Recent and Future Applications „PROMATECH“, ITMS 26220220186, supported by the Operational Program "Research and Development" financed through the European Regional

Development Fund. This work was supported by the Slovak Research and Development Agency under contract No. APVV-17-0008 and APVV-15-0202. Zuzana Molčanová, Beata Balloková, Juraj

Ďurišin, Katarína Šul'ová, Michaela Šuliková, Miloš Fejerčák and Karel Saksl are grateful to the Scientific Grant Agency of the Ministry of Education, Science, Research and Sport of the Slovak

Republic and the Slovak Academy of Sciences (VEGA projects No. 2/0013/19, 2/0080/17 and 1/0776/14). This work was carried out with the support of the Diamond Light Source, instrument I15-1 (proposal ee20770). We thank Dean Keeble for assistance in using beamline 115-1.

\section{REFERENCES}

[1] HOFMANN, Gunther O. and WAGNER, Frithjof D. New implant designs for bioresorbable devices in orthopaedic surgery. Clinical Materials. 1993. vol. 14, no.3, pp. 207-215.

[2] VICECONTI, Marco, MUCCINI, Roberto, BERNAKIEWICZ, Marek, BALEANI, Massimiliano and CRISTOFOLINI, Luca. Largesliding contact elements accurately predict levels of bone-implant micromotion relevant to osseointegration. Journal of Biomechanics. 2000. vol. 33, pp. 1611-1618.

[3] HERMAWAN, Hendra, DUBÉ, Dominique and MANTOVANI, Diego. Developments in metallic biodegradable stents. Acta Biomaterialia. 2010. vol. 6, pp. 1693-1697.

[4] HEIDEN, Michael, WALKER Emily K. and STANCIU Lia A. Magnesium, iron and zinc alloys, the trifecta of bioresorbable orthopaedic and vascular implantation - A review. 2015. Journal of Biotechnology and Biomaterials. 2015. vol. 5, no. 2, pp. 178 1-9. 
[5] ANSELME, Karine, PONCHE, Arnaud and BIGERELLE, Maxence. Relative influence of surface topography and surface chemistry on cell response to bone implant materials. Part 2: Biological aspects. In Proc. Inst. Mech. Eng. H 224: pp. 1487-1507.

[6] REN, Fang, WARD, Logan T., WILLIAMS, Travis, LAWS, Kevin J., WOLVERTON, Christopher M., HATTRICKSIMPERS, Jason R. and MEHTA, Apurva. Accelerated discovery of metallic glasses through iteration of machine learning and high-throughput experiments. Science Advances. 2018, vol. 4, no. 4, pp. 1566 1-11.

[7] QIU, Xiangyun, J.W. THOMPSON, Jeroen W. and BILLINGE Simon J.L. PDFgetX2: a GUI-driven program to obtain the pair distribution function from X-ray powder diffraction data, Journal of Applied Crystallography. 2004. vol. 37 , no. 4 , p. 678. 